\title{
OPTIMIZATION OF SOYBEAN DNA EXTRACTION UNDER DIFFERENT STORAGE AND DEVELOPMENT PERIODS
}

\author{
OTIMIZAÇÃO DE EXTRAÇÃO DE DNA DE SOJA SOB DIFERENTES PERÍODOS \\ DE ARMAZENAMENTO E DESENVOLVIMENTO
}

\begin{abstract}
Ana Carolina Oliveira MESQUITA ${ }^{\mathbf{1}}$; Adriana de Andrade FIGUEIRÓ ${ }^{\mathbf{2}}$; Karla Rodrigues COUTO ${ }^{3}$; Marília de Freitas OLIVEIRA $^{1}$; Fernando Cezar JULIATTI ${ }^{4}$

1. Graduação em Biotecnologia, Instituto de Genética e Bioquímica, Universidade Federal de Uberlândia - UFU, Uberlândia, MG, Brasil; 2. Pós-doutoranda, Instituto de Ciências Agrárias, Universidade Federal de Uberlândia - UFU, Uberlândia, MG, Brasil; 3. Doutoranda em Agronomia, Instituto de Ciências Agrárias, Universidade Federal de Uberlândia - UFU, Uberlândia, MG, Brasil; 4. Doutor, Professor, Instituto de Ciências Agrárias, Universidade Federal de Uberlândia - UFU, Uberlândia, MG, Brasil.
\end{abstract}

\begin{abstract}
DNA extraction of plants with high quality is very important to researches in molecular biology. Several extraction protocols have been used to obtain soybean DNA; however, there is a lack of papers about extraction protocols optimization and the best developmental stage of the plant to collect them. Therefore, the main purpose of the study was to extract high quantity and quality of DNA from fresh or frozen soybean samples, using different protocols. Moreover, we analyzed the best developmental stage of the plant to do the extraction. Fresh leaves or leaves kept for two years in the ultra-freezer were submitted to the DNA extraction protocols: Haberer et al., 1996 (modified); second modification from Haberer et al., 1996; Murray \& Thompson, 1980 (modified) e Doyle \& Doyle, 1990 (modified). Modified protocol of Doyle \& Doyle was used to value the best stage to collect the leaves to do the DNA extraction. The samples were collected in the stages of development VC, V1, V2, V3, V4 and R5. The experiments were conducted in completely randomized design with 10 samples per treatment. The data underwent variance analysis and the averages were compared by the Tukey test ( $\mathrm{p}<0.05)$. Through Doyle \& Doyle, 1990 and Haberer et al., 1996 modified protocols, for both fresh and frozen samples, it was possible to obtain a higher total DNA concentration if compared to the other tested protocols. However, the quality of DNAs extracted by the protocol Doyle \& Doyle, 1990 (modified) was superior, due to a minor molecular degradation. Besides that, the extractions made with these protocols have shown to be more efficient using frozen leaves' tissue. Higher DNA concentrations were obtained analyzing VC samples; however, there were no statistical differences between the stages VC, V2 and V3. It is suggested thereby to use modified of Doyle \& Doyle for DNA extraction from soybean leaves in V2 and V3 stages of development from frozen samples, providing the collect of a large number of samples and its storage until the analysis.
\end{abstract}

KEYWORDS: Glycine max. Molecular Biology. CTAB.

\section{INTRODUCTION}

DNA extraction of plants with high quality is important to researches in molecular biology (CANKAR et al., 2006). However, a lot of problems are described about its isolation and purification (MAZZA; BITTENCOURT, 2000). These obstacles are due to the high content of proteins, polysaccharides and secondary metabolites, like phenolic compounds, that can be extracted jointly with the DNA, affecting its quality (MALIYAKAL, 1992).

Vegetal DNA preparations are, commonly, used as substrates in Polymerase Chain Reactions (PCR) for phylogenetic studies or in the development of molecular markers, such as the microsatellites and the ones generated by Random Amplified Polymorphic DNA (RAPD). Regardless of the kind of molecular study, the DNA extractions must produce pure samples aiming not to inhibit enzymatic treatments or cause interference in the migration standards in electrophoresis gel (ROMANO; BRASILEIRO, 1999).

The DNA extraction method with most success for different species is the one based on the reagent CTAB (Cetyl Trimethylammonium Bromide). This detergent solubilizes membranes, forming a complex with the DNA that facilitates the posterior precipitation of the DNA molecule. Most protocols described in the literature uses the CTAB standard protocol, with some modifications in order to solve specific problems from the specie in study (ROMANO; BRASILEIRO, 1999).

Soybean (Glycine max), one of the main culture source of proteins and vegetable oils, has been studied a lot in molecular level. Various extraction methods are used to obtain the DNA with high quality from leaf tissues (EUROPEAN COMMISSION, 2011) and from other parts of the plant (SHARMA; GILL; SINGHDNA, 2002; DEMEKE; JENKINS, 2010). The choice of the best development stage of the plant to collect the 
samples is a new variable, in which a bigger quantity and quality of the molecule is searched.

Therefore, this study had the objective to extract soybean DNA from fresh and frozen samples, using different extraction protocols. Likewise, it was analyzed the best development stage of the plant for the total DNA extraction.

\section{MATERIAL AND METHODS}

The soybean genotype BRA 9R041001 RR was used for the total DNA extraction. For that, it was used young leaves collected in the presence of liquid nitrogen and stored leaves for about two years in the ultra-freezer $\left(-80^{\circ} \mathrm{C}\right)$.

Samples of soybean leaves were submitted to different DNA extraction protocols based on the method CTAB: Haberer et al., 1996 (modified); second modification by Haberer et al., 1996; Murray \& Thompson, 1980 (modified) and Doyle \& Doyle, 1990 (modified). The samples were macerated in liquid nitrogen and then submitted to the different protocols.

In the DNA extraction by the protocol Haberer et al. (1996) modified, $50 \mathrm{mg}$ of leaf tissues were homogenized with $650 \mu \mathrm{L}$ of buffer solution [Tris $1 \mathrm{M}$ (pH 8.0), EDTA 0,5 M (pH 8.0), $\mathrm{NaCl} 5$ $\mathrm{M}, \mathrm{CTAB} 2 \%$ ] heated in $65^{\circ} \mathrm{C}$ for 1 hour and $2 \%$ of $\beta$-mercaptoethanol was added. The samples were incubated in $65^{\circ} \mathrm{C}$ for $30 \mathrm{~min}$. After that, $550 \mu \mathrm{L}$ of chloroform/isoamyl alcohol (24:1) were added and centrifuged (5417R Eppendorf) at $10.000 \mathrm{rpm}$ for 10 min at room temperature. To the supernatant, $17 \%$ of RNAse (10 ng. $\mathrm{LL}^{-1}$ ) were added; the samples were incubated for $1 \mathrm{~h}$ at $37^{\circ} \mathrm{C}$. The DNA was precipitated with $67 \%$ of cool isopropanol, kept in $20^{\circ} \mathrm{C}$ for $15 \mathrm{~min}$ and centrifuged for $15 \mathrm{~min}$ at $14.000 \mathrm{rpm}$. The solution was discarded, the pellet was washed with $500 \mu \mathrm{L}$ of ethanol P.A. 7\%, centrifuged for $5 \mathrm{~min}$ at $14.000 \mathrm{rpm}$ and the ethanol was discarded. The pellets were dried overnight and resuspended in $30 \mu \mathrm{L}$ of deionized water.

A second modification of the modified protocol by Haberer et al. (1996) was tested. The leaf tissues $(50 \mathrm{mg})$ were homogenised in $650 \mu \mathrm{L}$ of buffer solution [Tris $1 \mathrm{M}(\mathrm{pH} 8.0)$, EDTA 0,5 M (pH 8.0), $\mathrm{NaCl} 5 \mathrm{M}, \mathrm{CTAB} 2 \%$, PVP 1\%] heated in $65^{\circ} \mathrm{C}$ for $1 \mathrm{~h}$ and $69 \mu \mathrm{L}$ of SDS $20 \%$ and $2 \%$ de $\beta$ mercaptoethanol were added. The samples were incubated in $65^{\circ} \mathrm{C}$ for $1 \mathrm{~h}$. After that, $550 \mu \mathrm{L}$ of chloroform/isoamyl alcohol (24:1) were added to the tubes and the samples were centrifuged at $10.000 \mathrm{rpm}$ for $10 \mathrm{~min}$ at room temperature. RNAse $17 \%\left(10 \mathrm{ng} . \mu \mathrm{L}^{-1}\right)$ was added to the supernatant and it was incubed for $1 \mathrm{~h}$ at $37^{\circ} \mathrm{C}$. Later, the DNA was precipitated with the same volume of cooled isopropanol and incubated at $-20^{\circ} \mathrm{C}$ for $2 \mathrm{~h}$. The samples were centrifuged for $15 \mathrm{~min}$ at $14.000 \mathrm{rpm}$. Then, the pellet was washed with $500 \mu \mathrm{L}$ of ethanol P.A. $76 \%+10 \mathrm{mM}$ of ammonium acetate, it was centrifuged for $5 \mathrm{~min}$ at $14.000 \mathrm{rpm}$. The pellets were dried overnight and resuspended in $100 \mu \mathrm{L}$ of TE 1X. The DNA was precipitated with $5 \mu \mathrm{L}$ of sodium acetate $+100 \mu \mathrm{L}$ of ethanol P.A. $95 \%$ and it was kept at $-20^{\circ} \mathrm{C}$ for $10 \mathrm{~min}$. A new centrifugation was done and the pellets were dried overnight. The DNA was resuspended in $30 \mu \mathrm{L}$ of deionized water.

To the DNA extraction using the protocol by Murray \& Thompson (1980) modified, $50 \mathrm{mg}$ of the leaf tissues were homogenized with $650 \mu \mathrm{L}$ of buffer solution [Tris $1 \mathrm{M}(\mathrm{pH} 8.0)$, EDTA $0.5 \mathrm{M}$ (pH 8.0), $\mathrm{NaCl} 5 \mathrm{M}$, CTAB 2\%, $69 \mu \mathrm{L}$ of SDS 20\%] heated at $65^{\circ} \mathrm{C}$ for $1 \mathrm{~h}$. The samples were incubated at $65^{\circ} \mathrm{C}$ for $60 \mathrm{~min}$ and centrifuged at $10.000 \mathrm{rpm}$ for $5 \mathrm{~min}$ at room temperature. To supernatant were added $315 \mu \mathrm{L}$ of phenol and $315 \mu \mathrm{L}$ of chloroform/isoamyl alcohol (24:1). The samples were centrifuged at $10.000 \mathrm{rpm}$ for $5 \mathrm{~min}$ and the DNA was precipitated with cooled 2/3 isopropanol for $20 \mathrm{~min}$ at $-20^{\circ} \mathrm{C}$. The samples were centrifuged for $6 \mathrm{~min}$ at $14.000 \mathrm{rpm}$. After that, the solution was discarded and the pellet was washed with $500 \mu \mathrm{L}$ of ethanol P.A. 70\%. A new centrifugation was made (5 min at $14.000 \mathrm{rpm}$ ) and the pellets were dried at $37^{\circ} \mathrm{C}$ for $2 \mathrm{~h}$. Then, $50 \mu \mathrm{L}$ de RNAse $\left(10 \mathrm{ng} . \mu \mathrm{L}^{-1}\right)$ were added with incubation for $30 \mathrm{~min}$ at $37^{\circ} \mathrm{C}$. A new precipitation of the DNA was made adding 5 $\mu \mathrm{L}$ of sodium acetate $3 \mathrm{M}$ and $100 \mu \mathrm{L}$ of ethanol P.A. 95\%, both iced. The samples were kept at $20^{\circ} \mathrm{C}$ for $10 \mathrm{~min}$ and centrifuged for $5 \mathrm{~min}$ at 14.000 rpm. The DNAs were washed with $300 \mu \mathrm{L}$ of cooled ethanol P.A. $70 \%$ and the pellets were dried at $37^{\circ} \mathrm{C}$ for $1 \mathrm{~h}$ and $30 \mathrm{~min}$. The DNAs were resuspended in $30 \mu \mathrm{L}$ of deionized water.

To the DNA extraction by the protocol Doyle \& Doyle (1990) modified, $50 \mathrm{mg}$ of leaf tissues were homogenized with $650 \mu \mathrm{L}$ of buffer solution [Tris $1 \mathrm{M}$ (pH 8.0), EDTA 0.5 M (pH 8.0), $\mathrm{NaCl} 5 \mathrm{M}$, CTAB 2\%, PVP $1 \%$ ] heated at $65^{\circ} \mathrm{C}$ for $1 \mathrm{~h}$ and $2 \% \quad \beta$-mercaptoethanol was added. The samples were incubated at $65^{\circ} \mathrm{C}$ for $1 \mathrm{~h}$ and $30 \mathrm{~min}$. Later, $650 \mu \mathrm{L}$ of chloroform-isoamyl alcohol (24:1) were added and the samples were centrifuged at $10.000 \mathrm{rpm}$ for $10 \mathrm{~min}$ at room temperature. The samples' DNA was precipitated with iced isopropanol with the same volume as in the sample. The samples were incubated at $-20^{\circ} \mathrm{C}$ for $2 \mathrm{~h}$ and centrifuged for $10 \mathrm{~min}$ at $14.000 \mathrm{rpm}$. The pellet was washed with $500 \mu \mathrm{L}$ of ethanol $76 \%$ and 10 $\mathrm{mM}$ of ammonium acetate. A new centrifugation 
was done (5 min at $14.000 \mathrm{rpm})$ and the pellets were dried at $37^{\circ} \mathrm{C}$ for $1 \mathrm{~h}$ and $30 \mathrm{~min}$. TE $1 \mathrm{X}(100 \mu \mathrm{L})$ were added to the samples and the DNA was precipitated with $5 \mu \mathrm{L}$ of sodium acetate and $100 \mu \mathrm{L}$ of ethanol P.A. $95 \%$. The tubes were kept at $-20^{\circ} \mathrm{C}$ for $10 \mathrm{~min}$ and centrifuged for $15 \mathrm{~min}$ at 14.000 rpm. The DNA was dried at $37^{\circ} \mathrm{C}$ for $1 \mathrm{~h}$ and 30 min. After that, $50 \mu \mathrm{L}$ of RNAse $\left(10 \mathrm{ng} . \mu \mathrm{L}^{-1}\right)$ were added and the resuspended samples were incubated for $30 \mathrm{~min}$ at $37^{\circ} \mathrm{C}$.

The protocol by Doyle \& Doyle, 1990 (modified) was used to value the best stage to collect soybean leaves to make the DNA extraction. The genotype NA 5909 503-026 was used in this experiment. The collects of soybean samples were made in different stages of development (FARIAS; NEPOMUCENO; NEUMAIER, 2007). At the vegetative phase the leaves were collected at $\mathrm{VC}$, $\mathrm{V} 1, \mathrm{~V} 2, \mathrm{~V} 3$ and V4. At the reproductive phase, the samples were collected at the R5 stage.

The samples' total DNA was quantified in NanoDrop 1000 Spectrophotometer (Thermo Scientific). The quality of the DNA was determined in agarose gel $0.8 \%(\mathrm{p} / \mathrm{v})$, in which de samples were stained with Red Gel (Biotium) diluted 1:500.

The experiments were conducted in completely randomized design using 10 samples per treatment. The data underwent variance analysis and the averages were compared by the Tukey test $(\mathrm{p}<0.05)$ with the aid of the program SISVAR 5.3 (FERREIRA, 2011).

\section{RESULTS AND DISCUSSION}

The problem of DNA extraction is still an important issue in the field of plant molecular biology. The successful PCR detection is dependent on the nature of the sample, suggesting that large amounts of substances can inhibit the amplification reaction of the target DNA (Poussier, 2002).

In this study, through the modified protocol Doyle \& Doyle (1990), was possible to obtain a higher DNA concentration using fresh samples; however, there was no significant difference between this one and the modified protocol by Haberer et al. (1996). The same can be observed when frozen samples were analyzed (Table 1).

Table 1. Average DNA concentration obtained using different extraction protocols of soybean leaves (Glycine $\max )$.

Modified protocols

\begin{tabular}{lll}
\multicolumn{1}{c}{ Modified protocols } & \multicolumn{2}{c}{$\begin{array}{c}\text { Average DNA concentration } \\
\left(\mathbf{n g . \mu \mathbf { L } ^ { - 1 }}\right)^{*}\end{array}$} \\
& \multicolumn{1}{c}{ Fresh samples } & \multicolumn{1}{c}{ Frozen samples } \\
\hline Haberer et al., 1996 & $2,243.67 \mathrm{Bab}$ & $3,533.63 \mathrm{Aa}$ \\
Haberer et al., 1996 (second modification) & $1,179.14 \mathrm{Abc}$ & $688.47 \mathrm{Ab}$ \\
Murray \& Thompson, 1980 & $366.88 \mathrm{Ac}$ & $927.23 \mathrm{Ab}$ \\
Doyle \& Doyle, 1990 & $2,778.06 \mathrm{Ba}$ & $4,071.87 \mathrm{Aa}$ \\
\hline
\end{tabular}

*Averages followed by the same capital letter within the same protocol do not differ; Averages followed by the same tiny letter in the column do not differ. Tukey Test $(\mathrm{p}<0.05)$.

It was possible to verify through the agarose gels that the four used extraction protocols were efficient in the soybean leaves DNA extraction, independent if the extractions were made with fresh samples or stored samples at $-80^{\circ} \mathrm{C}$. However, the DNAs extracted through the modified protocol by Doyle \& Doyle (1990) obtained a higher quality comparing to the other analyzed protocols, due to a less degradation of the molecule, shown in agarose gel $0.8 \%$ (data not submitted). Polysaccharide contamination is the most common problem affecting plant DNA purity. These carbohydrates can inhibit the activity of many molecular biological enzymes and can interfere with the concentration of DNA samples (Murray \& Thompson, 1980). The use of CTAB often results in DNA degradation (FANG et al., 1992).
The extractions were more efficient using frozen samples for both protocols Haberer et al., 1996 and Doyle \& Doyle, 1990. Nevertheless, through the modified protocol by Murray \& Thompson, 1980 and the second modification by Haberer et al., 1996, the DNA concentration didn't interfere statistically between fresh and frozen samples (Table 1).

Through the analysis of the development stages, it was possible to observe that the DNA concentration is directly connected to the stages in which the soybean plants are observed; that way, as younger the plant is at the collect stage, the higher will be the DNA concentration obtained. The stage with higher DNA concentration was observed at VC. However, there were no statistic differences between the stages VC, V2 and V3 (Table 2). 
Table 2. Average DNA concentration obtained at different development stages of soybean (Glycine max).

\begin{tabular}{cc}
\hline Stages & $\begin{array}{c}\text { Average DNA concentration } \\
\left(\mathbf{n g} \cdot \boldsymbol{\mu \mathbf { L } ^ { - 1 }}\right)^{*}\end{array}$ \\
\hline VC & $3,454.86 \mathrm{a}$ \\
V1 & $1,734.08 \mathrm{bc}$ \\
V2 & $2,338.22 \mathrm{ab}$ \\
V3 & $2,341.98 \mathrm{ab}$ \\
V4 & $1,582.00 \mathrm{bc}$ \\
R5 & $656.73 \mathrm{c}$ \\
\hline
\end{tabular}

*Averages followed by the same tiny letter in the column do not differ by the Tukey Test $(\mathrm{p}<0,05)$.

When the experiment needs live plants, it would be indicated the collect at the stages V2 and $\mathrm{V} 3$, because the plant would not die, which would happen doing the collect at the stage VC. The stage that showed the lowest DNA concentration was the R5. That is due to the fact that the plant had already achieved its maturity and, therefore, can have a bigger concentration of phenolic compounds (FRIGHETTO et al., 2012), which degraded the DNA (ROMANO, 1998).

\section{CONCLUSION}

It is suggested to use the modified protocol by Doyle \& Doyle, 1990 to make the DNA extraction of soybean leaves at the development stages V2 and V3, enabling the collect of a great amount of samples and its storage in the ultrafreezer before the accomplishment of the experiment.

\section{ACKNOWLEDGMENTS}

For Conselho Nacional de Desenvolvimento Científico e Tecnológico (CNPq), due to the financial support.

RESUMO: A extração de DNA de plantas com alta qualidade é de suma importância para pesquisas em biologia molecular. Diversos protocolos de extração vêm sendo utilizados para a obtenção de DNA de soja; contudo, há uma carência de trabalhos de otimização de protocolos de extração e de escolha do melhor estádio de desenvolvimento da planta para a coleta. Desta forma, o objetivo do estudo foi extrair DNA com alta quantidade e qualidade a partir de amostras frescas ou congeladas de soja, utilizando diferentes protocolos de extração. Além disso, foi analisado o melhor estádio de desenvolvimento da planta para a extração. Folhas frescas e armazenadas por cerca de dois anos em ultrafreezer foram submetidas aos protocolos de extração de DNA: Haberer et al., 1996 (modificado); segunda modificação de Haberer et al., 1996; Murray \& Thompson, 1980 (modificado) e Doyle \& Doyle, 1990 (modificado). Para a avaliação do melhor estádio de coleta das folhas para a extração de DNA foi utilizado o protocolo de Doyle \& Doyle modificado. As coletas de amostras foram realizadas nos estádios de desenvolvimento VC, V1, V2, V3, V4 e R5. Os experimentos foram conduzidos em delineamento inteiramente casualizado com 10 amostras por tratamento. Os dados foram submetidos à análise de variância e as médias comparadas pelo teste de Turkey $(\mathrm{p}<0,05)$. Através dos protocolos modificados de Doyle \& Doyle, 1990 e Haberer et al., 1996, tanto para amostras frescas como para congeladas, foi possível obter uma maior concentração de DNA total se comparado aos demais protocolos testados. Porém, a qualidade dos DNAs extraídos pelo protocolo Doyle \& Doyle, 1990 (modificado) foi superior, devido a menor degradação da molécula. Além disso, as extrações efetuadas com estes protocolos se mostraram mais eficientes quando foram utilizados tecidos foliares congelados. Maiores concentrações de DNA foram obtidas quando amostras em VC foram analisadas; porém, não houve diferença estatística entre os estádios VC, V2 e V3. Assim, sugere-se a utilização do protocolo modificado de Doyle \& Doyle para extração de DNA de folhas de soja nos estádios de desenvolvimento V2 e V3 a partir de amostras congeladas, viabilizando a coleta de um grande número de amostras e o seu armazenamento até a análise.

PALAVRAS-CHAVE: Glycine max. Biologia molecular. CTAB. 


\section{REFERENCES}

CANKAR, K.; STEBIH, D.; DREO, T.; ZEL, J.; GRUDEN, K. Critical points of DNA quantification by realtime PCR - effects of DNA extraction method and sample matrix on quantification of genetically modified organisms. BioMed Central Biotechnology, New York, v. 6, n. 37, p. 1-15, 2006.

DEMEKE, T.; JENKINS, G. R. Influence of DNA extraction methods, PCR inhibitors and quantification methods on real-time PCR assay of biotechnology-derived traits. Analytical and Bioanalytical Chemistry, Heidelberg, v. 396, n. 6, p. 1977-1990, 2010. http://dx.doi.org/10.1007/s00216-009-3150-9

DOYLE, J. J.; DOYLE, J. L. Isolation of plant DNA from fresh tissue. Focus, Washington, v. 1, p. 13-15, 1990.

EUROPEAN COMMISSION. Report on the validation on a DNA extraction method for ground soybeans. 2011. Disponível em: <http://gmo-crl.jrc.ec.europa.eu/summaries/BPS_CV127_DNAExtr_report.pdf>. Acesso em: 20 mar. 2014.

FANG, G.; HAMMAR, S.; GRUMET, R. A quick and inexpensive methods for removing polysaccharides from plant genomic DNA. BioFeedback, Michigan, v. 13., n. 1q, 1992.

FARIAS, J. R. B.; NEPOMUCENO, A. L.; NEUMAIER, N. Ecofisiologia da soja. Londrina: Embrapa Soja, 2007. 10 p. (Circular Técnica, 48).

FERREIRA, D. F. Sisvar: a computer statistical analysis system. Ciência e Agrotecnologia, Lavras, v. 35, n. 6, p. 1039-1042, 2011.

FRIGHETTO, R. T. S.; SÁBER, M. L.; BATISTA, E. R.; COSTA, L. B.; BACCAN, M. Efeitos da radiação ultravioleta B sobre cultivar de soja (Glycine max L. Merril) BRS 262, em condições de campo. In: WORKSHOP SOBRE MUDANÇAS CLIMÁTICAS E PROBLEMAS FITOSSANITÁRIOS, 2012, Jaguariúna. Anais... Jaguariúna: Embrapa Meio Ambiente, 2012.

HABERER, G.; FISCHER, T. C.; TORRES-RUIZ, R. A. Mapping of the nucleolus organizer region on chromosome 4 in Arabidopsis thaliana. Molecular and General Genetics, New York, v. 250, n. 1, p. 123-128, 1996. http://dx.doi.org/10.1007/s004380050058

MALIYAKAL, E. J. An efficient method for isolation of RNA and DNA from plants containing polyphenolics. Nucleic Acids Research, Oxford, v. 20, n. 9, p. 2381, 1992. http://dx.doi.org/10.1093/nar/20.9.2381

MAZZA, M. C. M; BITTENCOURT, J. V. M. Extração de DNA de tecido vegetal de Araucaria angustifolia (Araucariaceae). Boletim de Pesquisa Florestal, Colombo, n. 41, p.12-17, 2000.

MURRAY, M.; THOMPSON, W. F. Rapid isolation of high-molecular weight plant DNA. Nucleic Acid Research, Oxford, v. 8, p. 4321-4325, 1980. http://dx.doi.org/10.1093/nar/8.19.4321

POUSSIER, S.; CHERON, J. J.; COUTEAU, A.; LUISETTI, J. Evaluation of procedures for reliable PCR detection of Ralstonia solanacearum in common natural substrates. Journal of Microbiological Methods, Amsterdam, v. 51, n. 3, p. 349-359, 2012. http://dx.doi.org/10.1016/S0167-7012(02)00111-2

ROMANO, E. Extração de DNA de tecidos vegetais. In: BRASILEIRO, A.C.M.; CARNEIRO, V.T.C. (Ed). Manual de transformação genética de plantas. Brasília: Embrapa-SPI/ Embrapa-Cenargen, 1998. cap. 11, p. 163-177.

ROMANO, E.; BRASILEIRO, A. C. M. Extração de DNA de plantas: soluções para problemas comumente encontrados. Biotecnologia Ciência \& Desenvolvimento, Brasília, n. 9, p. 40-43, 1999.

SHARMA, A. D.; GILL, P.; SINGHDNA, P. Isolation from dry and fresh samples of polysaccharide-rich plants. Plant Molecular Biology Reporter, Athens, v. 20, n. 4, p. 415-415, 2002.

http://dx.doi.org/10.1007/BF02772129 